\title{
Developing Physics Learning Tools of Blended Learning Using Schoology with Problem-Based Learning Model
}

\author{
Dwi Ulan Rahmawati ${ }^{\text {a) }}$,umadi ${ }^{\text {b) }}$, Eko Mhd Ramadan ${ }^{\text {c) }}$ \\ Physics Education Departement, Yogyakarta State University, Yogyakarta, Indonesia \\ $\bowtie:{ }^{a)}$ dwi.ulan95@gmail.com, b)jumadi@uny.ac.id, c)ekomhd.2018@student.uny.ac.id
}

\begin{abstract}
This study is a development of research that aimed to (1) produce Physics learning tools based on blended learning that are suitable to be used in learning, and (2) determine the quality of learning tools that had been developed. This study used a 4D model, consisting of the defining, designing, developing and disseminating. The learning tools that had been developed consisted of Syllabus, Lesson Plan (RPP), Student Worksheet (LKPD), Handouts, and Learning Media of Web Schoology. The results of the development of learning tools established were included in the "excellent category" based on qualitative and quantitative assessments from expert lecturers, Physics teachers and peers with an average score of around $95-98$. In addition, the testing of learning tools was carried out to 33 students that showed an average score of students' response of 77.51, which was included in a "good category", used in the learning process of large - scale field tests. Furthermore, each phase of the implementation of the lesson plan was categorized very well for each meeting with the achievement of the score of observations of around $80 \%$ $100 \%$.
\end{abstract}

Keywords: blended learning, learning tools, problem based learning, web schoology

\section{INTRODUCTION}

The success of a country's development can be seen from the progress of its education. The availability of the education component is influenced by its supporting components. One component of educational development is the curriculum. The curriculum applied must be developed in accordance with the needs and challenges currently being faced. The curriculum is enhanced following the development of science, technology, cultural arts and competency guidelines to be achieved as educational goals. The Law Number 20 of 2003 of article 1 section 1 concerning the National Education System states that education is a conscious and planned effort to create an atmosphere of learning and learning process so that students can actively foster their potential to have religious spiritual strength, self-control, personality, intelligence, noble character, and the skills needed by themselves, society, nation and country (Regulation of Minister of Education and Culture Number 22 of 2016).

Indonesia education system is currently using the 2013 curriculum, a student-centered curriculum, in which the students find out the knowledge by themselves. The 2013 curriculum development covers many aspects of students' knowledge, attitudes and skills. Thus, the implementation of this curriculum encourages teachers to develop learning tools that are in accordance with the characteristics and needs of students be able to motivate them when taking part in class (Coca, 2017; Wiky 2017). The quality of the development of learning tools used by teachers must pay attention to many aspects in its preparation. Therefore, learning tools must be designed precisely and in line with the learning objectives to be achieved. 
There are two factors that determine the success or failure of learning in the classroom, including classroom management and teaching by the teacher (Yarid 2016). The classroom management includes learning tools arranged by the teacher with regard to the characteristics of students and the teaching by the teacher includes the suitability of the learning model with the material presented. Based on a study by Diani (2015), it was found that the Physics learning tools component used by the teacher did not support the achievement of the competencies to be achieved. One of them is because the lesson plan (RPP) used by teachers still did not have complete components, teaching materials and student worksheets (LKPD) were not suitable with the characteristics of students so that they were not able to optimize student achievement. Physics learning must be able to direct students in linking problems in everyday life with the concept of physics and provide experience in solving problems carried out by experiments that can make students play an active role.

A good teacher management system in the process of preparing the learning tools and the implementation phase in the classroom is needed so that it can help students easily understand the learning materials (Tsani 2019). One of learning model that can develop the ability to reason, reflect, collaborate and encourage students to be able to provide feedback is problem based learning model. (Forcael, Gonzalez, Orozco, Opazo, Suazo \& Aranguiz 2015), PBL model can improve learning achievement, critical thinking skills, collaboration skills and communication skills of students (Ismoyo, 2017; Sihalolo, Sahyar \& Ginting, 2017; Loyens, Jones, Mikkers \& Van Gog 2015). PBL model has been implemented in various ways. Face-to-face is the way most teachers use in implementing the PBL model (Savin 2007). However, in Kavcar's study (2017), it was found that teachers lack face-to-face time so that the material delivered is not optimal. One suggested step is to combine the concepts of Online and Offline in the PBL model learning process (Mayasari 2016).

The era is developing more rapidly and entering the 21 st century. The learning process is also experiencing significant changes in which one of the 21 st century skills is to direct students to be able to integrate ICT including the internet as a tool in the learning process (Al-Balushi 2015). The development of ICT merges with space and time so as to provide opportunities for teachers to be able to apply it in the learning process. In addition, the use of ICT can also provide opportunities for students to access learning anytime and anywhere (Suyosos \& Nurohman 2014).

This learning process is called blended learning, which is to switch the face-to-face process in class (real time) with no real time or in the form of discussion using online media (Hrastinski 2019, Cheung \& Wang 2019), such as Moodle, Schoology or Edmodo so that students can use it without space and time limits (Wijayanti 2017). In addition, the application of blended learning can improve the efficiency and effectiveness of time in the learning process (Murniati 2013). Moreover, blended learning can be one of answers for emergency states that causes a teacher unable to teach in class and it facilitates the students in accessing the learning process, even though it is carried out at home. One of the learning media that can help students in blended learning is web schoology, this media has complete features to help students in the online learning process (Ulva, Kantun \& Widodo 2018) and Schoology can improve cognitive, affective and psychomotor aspects in students (Hasanah, Suyanto \& Suana 2016).

Based on the explanation above, it is necessary to develop a learning device that can be an alternative answer to existing problems. A learning system that combines two online and offline systems in the learning process that can direct students to be active and can access learning material anywhere and anytime. One learning system that combines the two systems is called blended learning (Amalia 2017). Web schoology is used because it can be easily used by teachers and students to access it (Suana, Maharta, Nyeneng \& Wahyuni 2017). The use of the development of learning tools also provides benefits for students to be able to prepare for learning before entering class and provides a sense of responsibility in accessing the online learning process. Therefore, this study aims to develop a blended learning tool assisted by web schoology with the PBL model on the subject of static fluids.

\section{DEVELOPMENT OF LEARNING TOOLS}

\section{Syllabus}

Syllabus can be defined as a set of learning plans and assessments that are formulated by following certain systems or rules aimed at understanding basic competencies (Nadrag 2012). Syllabus is 
developed based on content standards and graduate competency standards (Rusman 2014). The syllabus is the most important and basic tool for managing the learning process (Fornaciari 2014). In the 2013 curriculum, the syllabus is defined as a plan for learning certain subjects that thoroughly contain competency standards, basic competencies, subject matter, learning activities, indicators, assessments, time allocation, and learning resources. Thus, the syllabus is the major element of a learning design that is made thoroughly following the applicable system or curriculum.

\section{Lesson Plan (RPP)}

In the Regulation of Minister of Education and Culture Number 22 of 2016, the standard process in preparing a lesson plan (RPP) is a scenario process in the learning process for every face-to-face period. Besides, the lesson plan is developed based on the basic competency (KD) objectives that can be reached by students after the learning process.

\section{Student Worksheet (LKPD)}

LKPD is one of the teaching materials that can support the Physics learning process of students. LKPD contains an assignment sheet that is adjusted to the steps in the learning process that have been selected according to the RPP (Mulyasa 2014). The use of LKPD can increase student activity during the learning process, increasing learning outcomes and creative abilities (Wandari, Kamid \& Maison, 2018).

\section{Handout}

Handouts are print media that are easily developed and used specifically in learning (Dick \& Carey 2015). In addition, handouts can also be used as an effort to enrich student knowledge (Sukmadinata 2012). A quality handout is explained in a concise and comprehensive manner and derived from the syllabus. Thus, the handout is a sheet of material that aims to help in the learning process that is compiled in a concise and comprehensive manner so as to enrich the knowledge of students.

\section{Blended Learning}

A learning process that combines the two components of the conventional and online methods is called blended learning (Amalia 2017). The combination of face-to-face learning with e-learning can produce effective, efficient and flexible learning (Laborda, 2014; Nurzzaman 2016). The implementation of blended learning is more effective in the learning process than using conventional learning (Owston 2013). In addition, the blended learning system is flexible so that it can be maximized in its use in the learning process (Dzuiban 2018).

\section{Learning Media of Web Schoology}

One of the web learning media namely Schoology presents web pages that offer learning in the classroom and are easy to use like Facebook (Suana 2017) (Alias 2012). Teachers can open wide opportunities for students to be actively involved in discussing and working together in groups to solve a problem using Schoology (Biswas, 2013; Rahmawati, Wilujeng, Jumadi, Kuswanto, Sulaeman \& Astuti 2020). The use of Schoology can help the process of blended learning, in which students can access material anywhere and anytime. In addition, Schoology can improve the cognitive, affective and psychomotor aspects of students (Hasanah 2016).

\section{RESEARCH METHODOLOGY}

The development procedure (Instructional Design) that will be used is the type of 4D model development includes 4 steps: (1) Define (2) Design (3) Develop and (4) Disseminate. The stages of the research procedure can be explained as shown in TABLE 1. 
TABLE 1. 4D STEPS

\begin{tabular}{|c|c|c|}
\hline 4D Steps & Action & Product \\
\hline Define & $\begin{array}{l}\text { 1. Preliminary Analysis } \\
\text { 2. Student Analysis } \\
\text { 3. Concept Analysis } \\
\text { 4. Formulation of Learning Objectives }\end{array}$ & $\begin{array}{l}\text { Guidelines for learning tools for blended } \\
\text { learning based on PBL models }\end{array}$ \\
\hline Design & $\begin{array}{l}\text { Make an initial draft of learning tools and } \\
\text { research instruments }\end{array}$ & Initial draft of learning tools \\
\hline Develop & $\begin{array}{l}\text { 1. Validation of initial draft by experts } \\
\text { 2. Revision } \\
\text { 3. Field Trial }\end{array}$ & $\begin{array}{l}\text { The final learning tools that has been } \\
\text { tested }\end{array}$ \\
\hline Disseminate & $\begin{array}{l}\text { Disseminate research results in the form of } \\
\text { publications and learning tools to teachers }\end{array}$ & Journals \\
\hline
\end{tabular}

\section{Participants}

The subjects of this study consisted of students, expert lecturers, Physics teachers and peers. The application of this learning tool was carried out in class XI MIA of SMAN 1 Sleman in the 2019/2020 academic year. It involved 2 expert lecturers, 3 Physics teachers and 5 peers.

\section{Data Collection Tools}

Data collection tools used were interviews, observation and questionnaires. The interviews were conducted with students and Physics teachers based on semi-structured questions and answers arranged with the aim to identify needs and obstacles during the process of learning Physics at school. The results of interviews that had been obtained become a guideline for developing the learning tools.

Validation sheets were used to determine the feasibility of products that had been developed, in which the questionnaire sheet was given to students to assess the readability of products that had been checked beforehand by expert lecturers. The observation sheet was used to inspect the general application of learning tool products that had been developed.

\section{Data Analysis}

Content validation was considered to be complete after being assessed by expert lecturers, consisting of lecturers, teachers and peers. The validators provided a validation assessment in the form of quantitative and qualitative data on the material, constructs and language. The quantitative assessment consisted of a validator score on the learning tools with an assessment category from 1 to 4 for each assessment of the indicator. The data that had been obtained was converted from quantitative and classified based on group scores obtained from the validation results of the product developed. Widoyoko (2017) made a classification based on comparison of the average ideal score (Xi) and the ideal standard deviation score (SBi). The qualification level was divided into four categories with the criteria shown in TABLE 2.

TABLE 2. Quality Score Classification

\begin{tabular}{cccc}
\hline No & Average Score Range & Achievement Criteria & Quality Category \\
\hline 1 & $X \geq X i+1.8 S B i$ & $X>85$ & Very Good \\
2 & $X i+0.6 S B i \leq X<X i+1.8 S b i$ & $70<X \leq 85$ & Good \\
3 & $X i-1.8 S B i \leq X<X i+0.6 S B i$ & $55<X \leq 70$ & Moderate \\
4 & $X<X i-1.8 S B i$ & $40<X \leq 55$ & Poor \\
\hline
\end{tabular}

The average ideal score (Xi) and ideal standard deviation score (SBi) can be determined using equations (1) and equation (2): 


$$
\begin{aligned}
& X i=\frac{i d e a l \text { maximum score }+ \text { ideal minimum score }}{2} \\
& S B i=\frac{\text { ideal maximum score }+ \text { ideal minimum score }}{6}
\end{aligned}
$$

The ideal maximum score is the theoretically ideal highest score of all items and the ideal minimum score is the assumption if the entire sample gives the lowest response.

\section{RESULTS AND DISCUSSION}

\section{Definiton}

At the defining stage, an analysis of the curriculum, students and concepts was carried out. The results of the analysis obtained that the learning process of Static Fluid in class XI MIA of SMAN 1 Sleman required a learning tool that can involve students to be active in the learning process and be able to connect examples with daily life. However, there were obstacles regarding the learning time in which the learning stages designed by the teacher were not completed in one meeting. Hence, a solution to this problem is needed. The learning process by combining two systems of online and offline or called blended learning can be a solution to this problem. The establishment of the learning tools developed included syllabus, lesson plans, handouts, LKPD and learning media. It is expected that the development of these tools can support the learning process to optimize thinking and cooperation activities among students. The results of unstructured interviews with teachers indicated that the learning process of students was less than optimal because the learning tools used had not been able to direct students to cooperate with each other in groups and had not optimized their thinking skills. One of the less optimal learning materials was Static Fluid material. An explanation of KI and KD of Static Fluid material can be seen in TABLE 3 below:

TABLE 3. Identification of Static Fluid Material

\begin{tabular}{ccc}
\hline Core Competency (KI) and Basic Competency (KD) & Material & Class / Semester \\
KI of 3 and $4, \mathrm{KD}$ of 3.3 and 4.3 & Static Fluid & XI/Odd \\
\hline
\end{tabular}

Next, the interviews were conducted with students regarding the learning process carried out by the teacher. The results of interviews indicated that students tend to get bored when they only listen to the teacher's explanation in class and rarely have a practicum. Moreover, students are allowed to bring smartphones and the internet networks in schools support the access to the internet. Yet, in the learning process, teachers have not utilized it very well.

\section{Design \\ Syllabus}

The syllabus concept contains the identity of the subject, including: the education unit, class, basic competency, subject matter, indicators, learning activities following the PBL model with the help of blended learning, media, assessment, time allocation and learning resources. The design of the syllabus matrix can be seen in FIGURE 1 below.

\section{Lesson Plan (RPP)}

The design of the RPP is based on the 2013 curriculum which refers to the regulation of the Regulation of Minister of Education and Culture Number 22 of 2016. The draft of the RPP of Static Fluid material was designed for meetings consisting of: school identity, core competency, basic competency, competency achievement indicators, teaching materials, learning activities, time allocation, learning methods, assessment and learning resources. The learning activities consisted of 5 meetings, divided into the initial test, meeting 1, meeting 2, meeting 3 and final test. Each meeting had a time allocation of $2 \times 45$ minutes for each meeting. The learning model used was the PBL model and the scientific approach. The design of the RPP can be seen in FIGURE 2 below. 

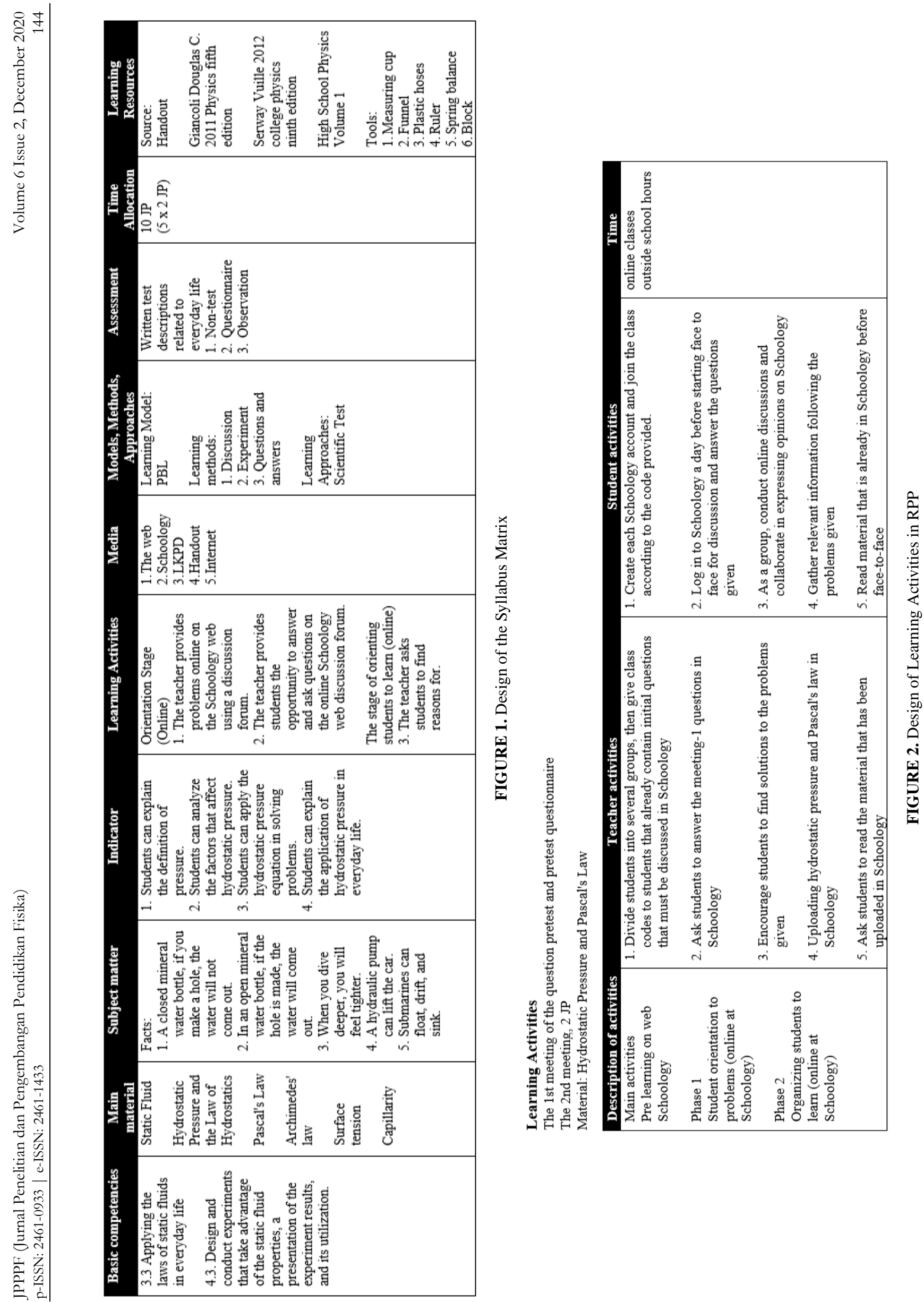


\section{Student Worksheet (LKPD)}

The worksheet designed contains the topic of questions, competencies to be achieved and work steps. The LKPD was designed for 3 meetings with different material, using the PBL model. The steps in data collection in LKPD were arranged to allow the students cooperate with each other and can solve the given problems. The design of LKPD is presented in FIGURE 3 below.
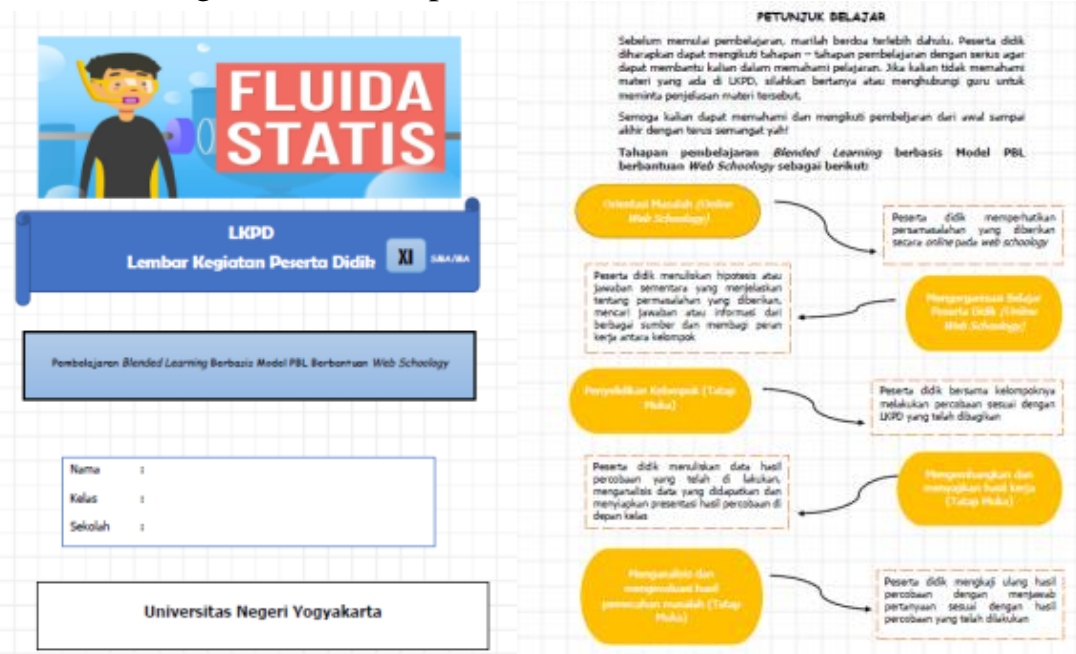

FIGURE 3. Design of LKPD

\section{Handout}

The handout contains a summary of Static Fluid material, formula equations, concepts, example questions, practice questions and stories about famous figures in the material developed by directing students to work together and think to solve the problems related to daily life. In addition, the handout material can be accessed online on the Web Schoology. Students can access the learning material before meeting in class (offline). Thus, the learning process time can be more optimal in the classroom. The design of the handout is presented in FIGURE 4 below.
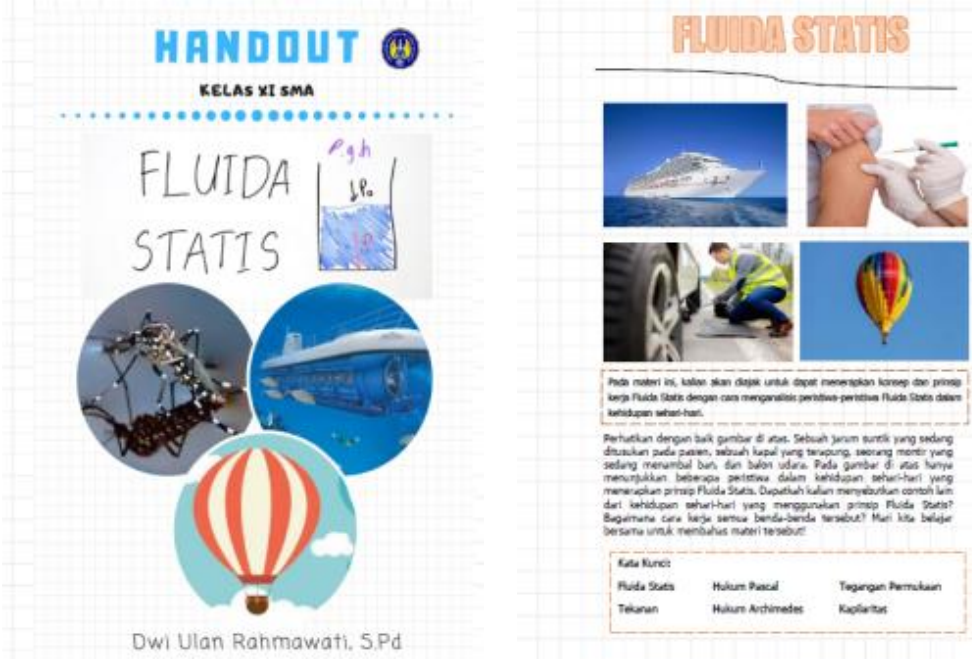

FIGURE 4. Design of Handout

\section{Learning Media of Web Schoology}

This media is assisted by Web Schoology in which students must first create an account to be able to join the Static Fluid class by entering the class code of ST9R-B49R-JXPP8. Then, students can 
follow the steps and instructions explained in each meeting folder that have been compiled. There are 3 meeting folders containing steps of the learning process following the PBL model and there are online and offline directions. In addition, by using this media, students can answer the teacher's questions in the comments column that have been provided and the notification will be received in the teacher's account so the teacher can record the students that have answered the problem or those who have not. The design of learning media of Web Schoology is presented in FIGURE 5 below.

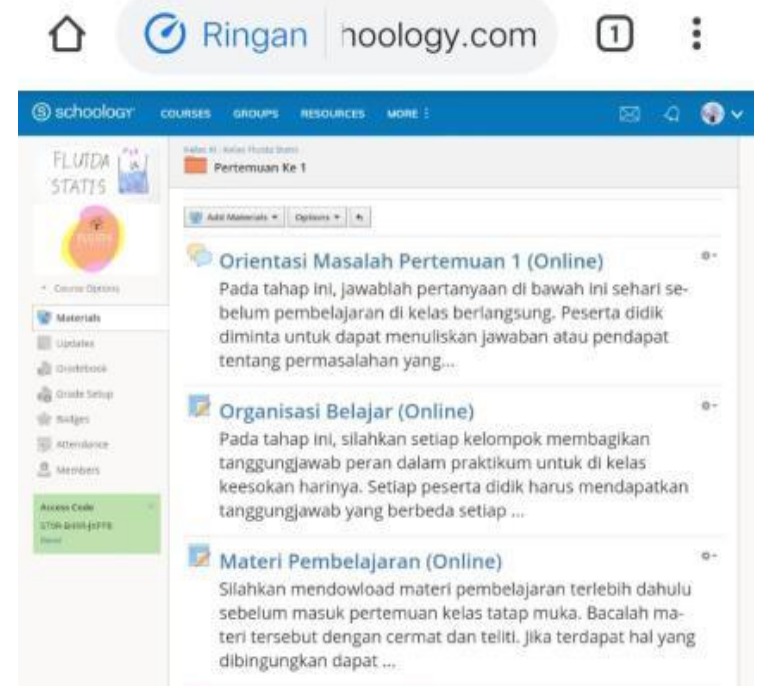

Melakukan Penyelidikan Kelompok (Tatap Muka) ․ Pada tahap ini peserta didik dengan masing-masing kelompok yang sudah ditentukan akan melaksanakan kegiatan praktikum. Kegiatan ini dilaksanakan di kelas secara tatap muka. Sillahkan mendowload ...

Menyajikan Hasil Karya (Tatap Muka) Pada tahap ini, peserta didik akan mempresentasikan hasil diskusi LKPD (Lembar Kerja Peserta Didik) yang sudah dikerjakan secara bersama dengan teman kelompok. Kegiatan ini dilakukan di kelas ...

Mengevaluasi Proses Pemecahan Masalah (Tatap ${ }^{\circ-}$ Muka)

Pada tahap ini, peserta didik bersama guru saling berd. iskusi tentang hasil jawaban pada LKPD yang telat dikerjakan. Keglatan ini dilaksanakan di kelas secara tatap muka. Peserta didik dapat...

FIGURE 5. Design of Learning Media of Web Schoology

\section{Development}

\section{Validity of Learning Tools}

The developed learning tools consist of syllabus, lesson plans, LKPD, handouts and learning media that were tested for feasibility with assessments from expert lecturers, Physics teachers and peers. The process of feasibility assessment of the learning tools used a feasibility sheet in accordance with the indicators that have been prepared. The results of the feasibility assessment of the syllabus are shown in Table 3. The TABLE 4 below is the results of the assessment carried out by expert lecturers, Physics teachers and peers. It obtained a mean of 42.86 , which was converted into a five scale score, so that a score of 97.4 was obtained. Based on the achievement criteria in Table 1, the syllabus developed is included in the excellent category and can be used in the learning process.

TABLE 4. Syllabus Assessment Results by Experts

\begin{tabular}{ccc}
\hline No. & Aspect & Mean \\
\hline 1 & Completeness of Component and Syllabus Identity & 7.77 \\
2 & Formulation of Indicators & 4 \\
3 & Learning Activities & 7.55 \\
4 & Learning Materials & 7.77 \\
5 & Learning Assessment & 4 \\
6 & Time & 4 \\
7 & Language & 7.77 \\
& Total & 42.86 \\
& Maximum Score & 100 \\
\hline & Score & $\mathbf{9 7 . 4}$
\end{tabular}

The results of the RPP assessment are shown in TABLE 5. The results of the RPP assessment by 8 assessors obtained a mean of 95.3, so that the RPP developed is categorized as very good and can be used in the learning process. 
TABLE 5. RPP Assessment Results by Experts

\begin{tabular}{ccc}
\hline No. & Aspect & Mean \\
\hline 1 & Subject Identity & 4 \\
2 & Core Competency (KI) & 4 \\
3 & Basic Competency (KD) & 4 \\
4 & Learning Indicators & 3.5 \\
5 & Learning Objectives & 3.8 \\
6 & Teaching Materials & 11.5 \\
7 & Time Allocation & 4 \\
8 & Learning approaches, models and methods & 7.3 \\
9 & Learning Activities & 7.6 \\
10 & Assessment & 3.5 \\
11 & Learning Resources & 4 \\
& Total & 57.2 \\
& Maximum Score & 100 \\
\hline & Score & $\mathbf{9 5 . 3}$ \\
\hline
\end{tabular}

The results of the handout assessment are shown in TABLE 6. The results of the handout assessment by 9 assessors obtained a mean of 98.34, so the handouts developed are categorized as very good and can be used in the learning process.

TABLE 6. Handout Assessment Results by Experts

\begin{tabular}{ccc}
\hline No. & Aspect & Mean \\
\hline 1 & Feasibility of Content Component & 23.27 \\
2 & Feasibility of Language & 39.67 \\
& Total & 63.27 \\
& Maximum Score & 100 \\
\hline & Score & $\mathbf{9 8 . 3 4}$ \\
\hline
\end{tabular}

The LKPD Assessment Results are shown in TABLE 7. The LKPD assessment results by 8 assessors obtained a mean of 96.17, so the LKPD developed is included in the excellent category and can be used in the learning process.

TABLE 7. LKPD Assessment Results by Experts

\begin{tabular}{ccc}
\hline No. & Aspect & Mean \\
\hline 1 & Feasibility of Content Component & 30.23 \\
2 & Feasibility of Presentation & 19.66 \\
3 & Feasibility of Language & 11.66 \\
& Total & 61.55 \\
& Maximum Score & 100 \\
\hline & Score & $\mathbf{9 6 . 1 7}$ \\
\hline
\end{tabular}

The results of the Learning Media of Web Schoology assessment are shown in TABLE 8. The results of the learning media assessment by 10 assessors obtained a mean of 95.5 , so that the media developed are categorized as very good and can be used in the learning process.

TABLE 8. Learning Media of Web Schoology Assessment Results by Experts

\begin{tabular}{ccc}
\hline No. & Aspect & Mean \\
\hline 1 & System Quality & 14.2 \\
2 & Information/Content Quality & 15.2 \\
3 & Delivery System Method & 8.8 \\
& Total & 38.2 \\
& Maximum Score & 100 \\
\hline & Score & $\mathbf{9 5 . 5}$ \\
\hline
\end{tabular}

Overall, the results of the assessment of the feasibility of the learning tools developed are presented in FIGURE 6. Based on the results obtained, the learning tools developed are included in the excellent category and can be used in the learning process. 


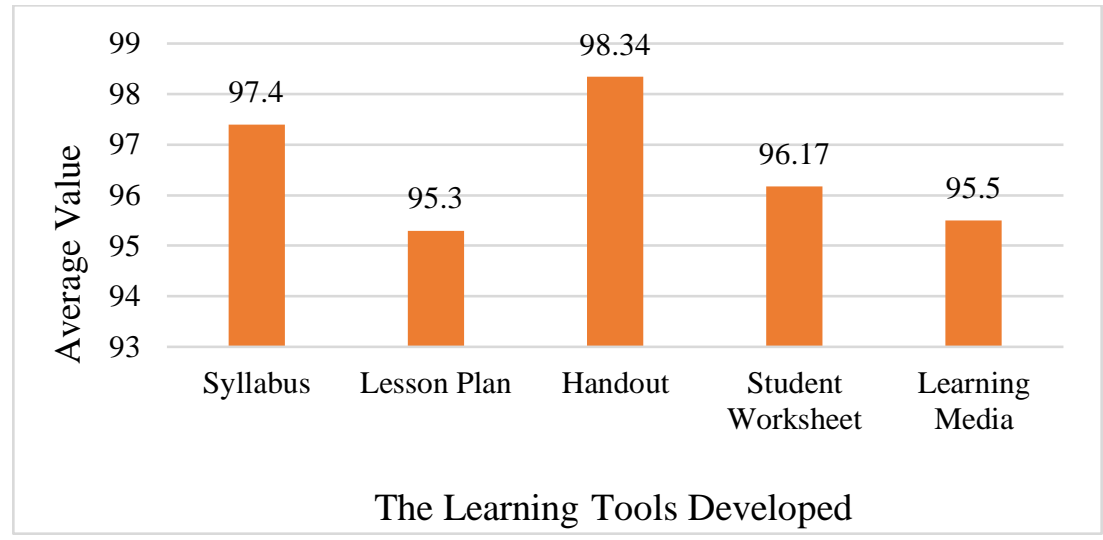

FIGURE 6. The results of the feasibility assessment of the learning tools

The results of the validation of the product feasibility assessment indicate that the learning tools consisting of Syllabus, Lesson Plans, Handouts, Student Worksheets, and Learning media get an average score of more than 90 . However, comments or suggestions for improvements are also obtained, including: (1) improvements in writing formula, (2) arranging sentences in the handout, (3) improving the appearance of tasks on the Schoology web, and (4) improving the LKPD sentences.

In addition, the validation results also show that the learning tools developed are in the "Very Good" category. Based on the results of validation or product feasibility similar to the results of research, namely the blended learning device assisted by web Schoology with the PBL model is declared feasible and can be used in the learning process (Rosmiati, Jatimiko \& Madlazim, 2017; Pratiwi, 2020).

\section{Student Response Results}

Students provided an assessment response to the learning tools that has been assessed for the feasibility by the validators. On this occasion, 33 students gave an assessment response to the learning tools which included the implementation of the RPP, LKPD, PBL Model, Blended Learning and Web Schoology. Further, students provided comments, suggestions and criticisms of the development of learning tools that have been used. The results of the assessment response are presented in TABLE 1 above, in which the assessment obtained is converted to a five scale score (Widyoko, 2017). The results of students' assessment response to the products developed are presented in TABLE 9 below.

TABLE 9. Assessment Results of Product Testing

\begin{tabular}{|c|c|c|c|c|}
\hline No. & $\begin{array}{c}\text { Total of } \\
\text { Students }\end{array}$ & Aspect & Score & Category \\
\hline 1 & \multirow{5}{*}{33} & Application of RPP & 75.9 & Good \\
\hline 2 & & LKPD & 84.13 & Very Good \\
\hline 3 & & PBL Model & 79.55 & Good \\
\hline 4 & & Blended Learning & 75.25 & Good \\
\hline 5 & & Web Schoology & 72.75 & Good \\
\hline \multicolumn{3}{|c|}{ Total } & \multicolumn{2}{|c|}{387.58} \\
\hline \multicolumn{3}{|c|}{ Maximum Score } & \multicolumn{2}{|c|}{100} \\
\hline \multicolumn{3}{|c|}{ Mean } & 77.51 & Good \\
\hline
\end{tabular}

The results of the students' responses showed that the learning tools developed obtained a mean of 77.51 , including in the "good" category. Students also give a positive response to the tools that have been developed. Generally, the students comment that by using this learning tool, they can be independent in the learning process and have the initial ability to access online learning first on the web Schoology. This is similar to that web Schoology can improve cognitive, affective, and psychomotor aspects in students (Hasanah, Suyanto \& Suana, 2016; Rahmawati, Wilujeng, Jumadi, Kuswanto, Sulaeman \& Astuti, 2020). But if you want blended learning to improve students' understanding of data and processing data, teachers should use data from adaptive digital content for differentiation. This is because blended learning forces students to study with digital systems (Fazal, Panzano, \& Luk 2019). 


\section{Implementation of Learning}

The results of the implementation of the learning process in the field were assessed by two observers. The results of the assessment of the observers are transformed into quantitative data presented in FIGURE 7 below, so that the activities at each stage for the meeting in the learning process can be seen. The results obtained that the process of implementing the lesson plan at each stage is in the very good category, in which every meeting has $80 \%-100 \%$ achievement.

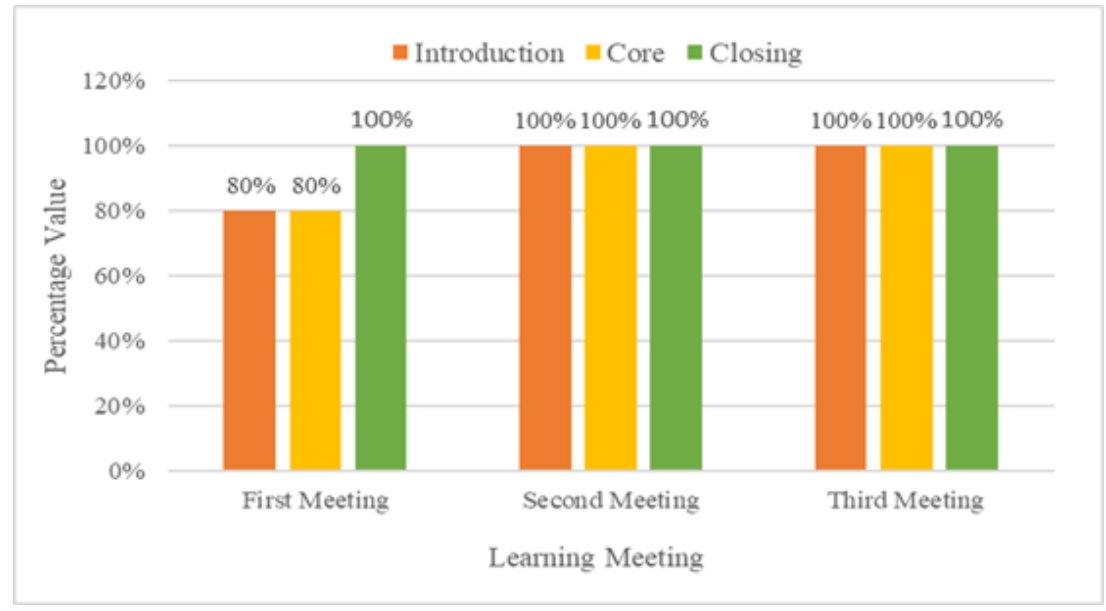

FIGURE 7. Results of Learning Implementation Observation

The results of the RPP implementation process at each stage obtained a score range between $80 \%$ $100 \%$. This is because at the first meeting there were still students who were not familiar with the combination of learning systems. However, when the next learning meeting process students are used to and can attend online and offline classes properly so that all stages in the PBL model can be carried out effectively and efficiently. Learning using blended learning assisted by web Schoology can use time efficiently and effectively in the learning process (Stockwell, 2015; Kuo \& Hwang, 2014; Agustianto, Permanasari \& Hidayah 2015; Waluya \& Mariani, 2018). In addition, when the experimental process in the offline classroom students can work together with group members well so that experimental activities can be carried out well (Ismoyo, 2017; Sihalolo, Sahyar \& Ginting, 2017; Loyens, Jones, Mikkers \& Van Gog, 2015).

\section{CONCLUSION}

The conclusions of this study are (1) learning tools of blended learning using Web Schoology with problem-based learning model on Static Fluid material has been produced. The learning tools developed are syllabus, lesson plans, handouts, LKPD and learning media of Web Schoology; (2) The results of expert validation test show that the product developed has a "very good" quality with the acquisition of score for syllabus (97.4); RPP (95.3); Handout (98.34); LKPD (96.17); and learning media of Web Schoology (95.5); (3) The practicality test result obtained from the students' response is 77.51 in the "good category". Thus, it obtained the results of the development of learning tools that are practical and feasible to use.

\section{REFERENCES}

Agustianto, K, Permanasari, AE \& Hidayah, I 2015, 'Perancangan Blended E-Learning Berbasis Problem-Based Learning Untuk Mendukung Adaptive Learning', Semnasteknomedia Online, vol. 3, no. 1, pp. 3-5. 
Al-Balushi, SM \& Al-Abdali, NS 2015, 'Using a Moodle-based professional development program to train science teachers to teach for creativity and its effectiveness on their teaching practices', Journal of Science Education and Technology, vol. 24, no. 4, pp. 461-75.

Alias, N \& Siraj, S 2012, 'Design and Development of Physics Module Based on Learning Style and Appropriate Technology by Employing Isman Instructional Design Model', Turkish Online Journal of Educational Technology-TOJET, vol. 11, no. 4, pp. 84-93.

Amalia, AF 2017, 'Penerapan metode blended learning berbasis tik untuk meningkatkan pemahaman konsep pada matakuliah listrik magnet ii', Sosiohumaniora: Jurnal Ilmiah Ilmu Sosial Dan Humaniora, vol. 3, no. 1.

Biswas, S 2013, 'Schoology-supported classroom management: A curriculum review', Northwest Journal of Teacher Education, vol. 11, no. 2, p. 12.

Cheung SKS \& Wang FL 2019, "Blended learning in practice: guest editorial" Journal of Computing in Higher Education, vol. 31, pp. 229-232, DOI: 10.1007/s12528-019-09229-8.

Coca, DM \& Sliško, J 2017, 'Software Socrative and smartphones as tools for implementation of basic processes of active physics learning in classroom: An initial feasibility study with prospective teachers', European Journal of Physics Education, vol. 4, no. 2, pp. 17-24.

Diani, R 2015, 'Pengembangan perangkat pembelajaran fisika berbasis pendidikan karakter dengan model problem based instruction', Jurnal Ilmiah Pendidikan Fisika Al-Biruni, vol. 4, no. 2, pp. 243-55.

Dick, W, Carey, L \& Carey, JO 2005, 'The systematic design of instruction'.

Dziuban, C, Graham, CR, Moskal, PD, Norberg, A \& Sicilia, N 2018, 'Blended learning: the new normal and emerging technologies', International Journal of Educational Technology in Higher Education, vol. 15, no. 1, p. 3.

Fazal M, Panzano B, \& Luk K 2020, "Evaluating the Impact of Blended Learning: a Mixed-Methods Study with Difference-in-Difference Analysis", TechTrends, vol. 64, pp.70-78, DOI: 10.1007/s11528-019-00429-8.

Forcael, E, González, V, Orozco, F, Opazo, A, Suazo, Á \& Aránguiz, P, 2015, 'Application of problembased learning to teaching the critical path method', Journal of Professional Issues in Engineering Education and Practice, vol. 141, no. 3, p. 04014016.

Fornaciari, CJ \& Lund Dean, K 2014, 'The 21st-century syllabus: From pedagogy to andragogy', Journal of Management Education, vol. 38, no. 5, pp. 701-23.

Hasanah, N, Suyanto, E \& Suana, W 2016, 'E-learning dengan Schoology Sebagai Suplemen Pembelajaran Fisika Materi Elastisitas dan Hukum Hooke', Jurnal Pembelajaran Fisika, vol. 4 , no. 2.

Hrastinski S 2019, "What Do We Mean by Blended Learning?", TechTrends, vol. 63, pp.564-569, DOI: 10.1007/s11528-019-00375-5.

Indonesia, PR 2017, 'Permendikbud No. 22 Tahun 2016 tentang Standar Proses Pendidikan Dasar dan Menengah'.

Ismoyo, H 2017, 'Effect Of Problem-Based Learning On Improvement Physics Achievement And Critical Thinking Of Senior High School Student', Journal of Baltic Science Education, vol. 16 , no. 5 .

Kavcar, N \& Erdem, A 2017, 'Analysis of physics textbooks for 10th and 11th grades in accordance with the 2013 secondary school physics curriculum from the perspective of project-based learning', In AIP Conference Proceedings, AIP Publishing LLC, vol. 1815, no. 1, p. 070006.

Kuo, FR \& Hwang, GJ 2014, 'A five-phase learning cycle approach to improving the web-based problem-solving performance of students', Journal of Educational Technology \& Society, vol. 17 , no. 1 , pp. $169-84$.

Laborda, JG 2014, 'Stein, Jared \& Graham, Charles R (2014) Essentials for blended learning Routledge (New York \& London) isbn 978-0-415-63616-2 $210 \mathrm{pp£} 19.99 \mathrm{http} / / / \mathrm{www}$. routledge. com/books/details/9780415636162', British Journal of Educational Technology, vol. 45, no. 4, pp. E23-24.

Loyens, SM, Jones, SH, Mikkers, J \& van Gog, T 2015, 'Problem-based learning as a facilitator of conceptual change', Learning and Instruction, vol. 38, pp. 34-42. 
Mayasari, T, Kadarohman, A, Rusdiana, D \& Kaniawati, I 2016, 'Apakah model pembelajaran problem based learning dan project based learning mampu melatihkan keterampilan abad 21?', Jurnal Pendidikan Fisika Dan Keilmuan (JPFK), vol. 2, no. 1, pp. 48-55.

Mulyasa, E 2014, 'Guru dalam implementasi kurikulum 2013', Bandung: PT Remaja Rosdakarya Offset.

Murniati, DR \& Sanjaya, I 2013, 'Pengembangan Perangkat Pembelajaran Kimia Berbasis Blended Learning Di Sma Negeri 7 Kediri (Development Of Chemistry Learning Kit Based On Blended Learning At Sma Negeri 7 Kediri)', Unesa Journal Of Chemical Education, vol. 2, no. 3.

Nadrag, L \& Soare 2012, 'A. Syllabus Versus Curiculum', Studi Gi Cercetri Filologice, vol. 40.

Nuruzzaman, A 2016, 'The Pedagogy of Blended Learning: A Brief Review', IRA International Journal of Education and Multidisciplinary Studies, vol. 4, no. 1, pp. 125-34.

Owston, R, York, D \& Murtha, S 2013, 'Student perceptions and achievement in a university blended learning strategic initiative', The Internet and Higher Education, vol. 18, pp. 38-46.

Pratiwi, NLPA 2020, 'Pengembangan Media Pembelajaran E-Learning Model Blended Learning Berbantuan Schoology Pada Mata Pelajaran Sistem Komputer Kelas X Multimedia Di Smk Negeri 1 Sawan (Doctoral Dissertation, Universitas Pendidikan Ganesha)'.

Rahmawati, DU, Wilujeng, I, Jumadi, J, Kuswanto, H, Sulaeman, NF \& Astuti, DP 2020', Problem Based Learning E-Handout: Improving Students' Mathematical Representation and Self Efficacy', Jurnal Ilmiah Pendidikan Fisika Al-Biruni, vol. 9, no. 1, pp. 41-50.

Rosmiati, R, Jatmiko, B \& Madlazim, M 2017, 'Pengembangan Perangkat Pembelajaran Blended Learning Model Cooperative Untuk Meningkatkan Hasil belajar Fisika Sma Kelas Xi', Jpps (Jurnal Penelitian Pendidikan Sains), vo. 3, no. 1, pp. 294-98.

Rusman 2014, 'Model-Model Pembelajaran Mengembangkan Profesional Guru', Jakarta: Raja Grafindo Persada.

Savin, Maggi \& Baden 2007', A Particular Guide to Problem-based Learning Online', New York: Routledge.

Sihaloho, RR, Sahyar, S \& Ginting, EM 2017, 'The effect of Problem Based Learning (PBL) model toward student's creative thinking and problem solving ability in senior high school', IOSR Journal of Research \& Method in Education (IOSRJRME), vol. 7, no. 4, pp. 11-8.

Stockwell, BR, Stockwell, MS, Cennamo, M \& Jiang, E 2015, 'Blended learning improves science education', Cell, vol. 162, no. 5, pp. 933-36.

Suana, W, Maharta, N, Nyeneng, ID \& Wahyuni, S 2017, 'Design and implementation of schoologybased blended learning media for basic physics I course', Jurnal Pendidikan IPA Indonesia, vol. 6 , no. 1.

Sukmadinata, NS \& Syaodih, E 2012, 'Kurikulum dan Pembelajaran Kompetensi', Bandung: PT. Refika Aditama.

Suyoso, S \& Nurohman, S 2014, 'Pengembangan Modul Elektronik Berbasis Web Sebagai Media Pembelajaran Fisika', Jurnal Kependidikan: Penelitian Inovasi Pembelajaran, vol. 44, no. 1.

Tsani, I, Yasin, M, Zuroidah, N, Huda, S, Lestari, F \& Rahmat, A 2019, 'Management development of student worksheets to improve teacher communication skills: A case study self-efficacy and student achievement', Journal for the Education of Gifted Young Scientists, vol. 7, no. 4, pp. 777-98.

Ulva, NL, Kantun, S \& Widodo, J 2018, 'Penerapan E-Learning Dengan Media Schoology Untuk Meningkatkan Motivasi Dan Hasil Belajar Siswa Pada Kompetensi Dasar Mendeskripsikan Konsep Badan Usaha Dalam Perekonomian Indonesia', Jurnal Pendidikan Ekonomi: Jurnal Ilmiah Ilmu Pendidikan, Ilmu Ekonomi Dan Ilmu Sosial, vol. 11, no. 2, pp. 96-102.

Wandari, A, Kamid, K \& Maison, M 2018, 'Pengembangan Lembar Kerja Peserta Didik (LKPD) pada Materi Geometri berbasis Budaya Jambi untuk Meningkatkan Kreativitas Siswa', Edumatika: Jurnal Riset Pendidikan Matematika, vol. 1, no. 2, pp. 47-55.

Widyoko, SEP, 2017, 'Teknik Penyusunan Instrumen Penelitian (6th ed)', Yogyakarta: Pustaka Belajar.

Wijayanti, W, Maharta, N \& Suana, W 2017, 'Pengembangan perangkat blended learning berbasis learning management system pada materi listrik dinamis', Jurnal Ilmiah Pendidikan Fisika AlBiruni, vol. 6, no. 1, pp. 1-12, DOI:10.24042/jpifalbiruni.v6i1.581. 
Wiky Dakosta, Andrian 2017, 'Pengembangan Lembar Kerja Siswa Berbasis Model Siklus Belajar 7e Pada Submateri Hukum Archimedes Sebagai Sarana Pembelajaran Fisika Di Sma Al-Islam Krian', Inovasi Pendidikan Fisika, vol. 6 no. 3.

Yarid, H \& Ariswan, A 2016, 'Pengembangan perangkat pembelajaran fisika problem based learning melalui kegiatan fieldtrip pada materi energi', Jurnal Inovasi Pendidikan IPA, vol. 2, no. 1, pp. 2434. 